\title{
Molecular detection and occurrence of equine theileriosis in Arabian horses in Al-Najaf province/Iraq
}

\author{
Detecção molecular e prevalência de teileriose equina em cavalos árabes \\ na província de Al-Najaf/Iraque
}

\author{
Hayder Mohammad Al-Rammahi ${ }^{1}$ (D), Abdulameer Abed Hatem ${ }^{1}$, Asaad Chasib Al-Atabi ${ }^{1}$ \\ ${ }^{1}$ University of Kufa, Faculty of Veterinary Medicine, Kufa, Iraq
}

\begin{abstract}
This study was designed to detect equine piroplasmosis using the molecular technique in Al-Najaf province during the season that showed an increment in tick activities. Blood samples were collected from 110 horses with more than two signs of piroplasmosis. After DNA extraction, the product was examined by a polymerase chain reaction to amplify $18 \mathrm{SrRNA}$. The results showed that the overall percentage of equine theileriosis was $38.18 \%$. According to gender, the percentage of infection was $43.48 \%$ and $29.27 \%$ in females and males, respectively. Significant variations appeared between infected horses according to age, and the percentage of infection was 50\% and $35.22 \%$ in less than 2 years and more than 2 years age, respectively. Moreover, the percentage of infection was $62.5 \%$ and $19.35 \%$ in animals with and without acariasis, respectively. Significant variations were also seen in equine theileriosis according to geographical areas, and the higher percentage was reported in Hera district (60.87\%), while the lowest percentage was in the center of Al-Najaf (21.43\%). This difference may be due to different distribution of vector of disease (tick), which may be the availability of the suitable weather that helped in the multiplication of the intermediate vectors. In conclusion, this study proved the variations in the occurrences of equine piroplasmosis according to gender, age, and geographical areas.
\end{abstract}

Keywords: Equine theileriosis. PCR. Al-Najaf horses. Piroplasmosis.

\section{RESUMO}

Este estudo foi desenvolvido para detectar piroplasmose equina usando a técnica molecular na província de Al-Najaf durante o período do ano com maior ocorrência de carrapatos. Foram coletadas amostras de sangue de 110 cavalos que apresentaram mais de dois sinais de piroplasmose. Após a extração do DNA, o produto foi examinado por reação em cadeia da polimerase para amplificar o $18 \mathrm{SrRNA}$. Os resultados mostraram que a porcentagem geral de teileriose equina foi de $38,18 \%$. De acordo com o sexo, o percentual de infecção foi $43,48 \%$ e $29,27 \%$ no sexo feminino e masculino, respectivamente. Apareceram variações significativas entre os cavalos infectados de acordo com a idade, e a porcentagem de infecção foi $50 \%$ e 35,22\% em menos de 2 anos e mais de 2 anos, respectivamente. Além disso, as porcentagens de infecção foram 62 , 5\% e 19, 35\% em animais com e sem acariasis, respectivamente. Também foram observadas variações significativas na teileriose dos equídeos, de acordo com as áreas geográficas, e o maior percentual foi relatado no distrito de Hera (60,87\%), enquanto o menor percentual foi no centro de Al-Najaf (21,43\%). Essa diferença pode ser devido à distribuição diferente do vetor da doença (carrapato), que pode ser a disponibilidade do clima adequado que ajuda na multiplicação dos vetores intermediários. Em conclusão, este estudo provou as variações nas ocorrências de piroplasmose eqüina de acordo com sexo, idade e áreas geográficas.

Palavras-chave: Teileriose eqüina. PCR. Cavalos de Al-Najaf. Piroplasmose. 
Correspondence to:

Hayder Mohammad Al-Rammahi

University of Kufa, Faculty of Veterinary Medicine

PO Box 21, Najaf Governorate, Iraq

e-mail: hayderm.alrammahi@uokufa.edu.iq

Received: February 21, 2020

Approved: June 26, 2020

How to cite: Al-Rammahi HM, Hatem AA, Al-Atabi AC. Molecular detection and occurrence of equine theileriosis in Arabian horses in Al-Najaf province/Iraq. Braz J Vet Res Anim Sci. 2020;57(3):e166996. https://doi.org/10.11606/ issn.1678-4456.bjvras.2020.166996

\section{Introduction}

Equine theileriosis caused by apicomplexan Theileria equi is a disease of economic importance facing the equine population in endemic areas (Kumar et al., 2007). According to the occurrence of biological vectors (21 tick species of genera Rhipicephalus, Dermatocentor, Hyaloma, and Boophilus), equine theileriosis is distributed in Asia, Africa, Europe and South America (Schein, 1988; Wise et al., 2013). The disease is manifested by clinical and subclinical forms, the clinical form characterized by hemolytic anemia, in addition to systemic signs including fever, anorexia, jaundice, and dyspnea, edema of limbs, colic, hemoglobinuria and death (Butler et al., 2012; Waal, 1992; Zobba et al., 2008). However, subclinically infected horses have represented a reservoir infecting vectors (Friedhoff et al., 1990).

Acute equine theileriosis is easily diagnosed by microscopic examination of blood smears (Mahdy et al., 2016), while in the chronic or carrier stage, the serological technique is required for diagnosis. Lack of sensitivity is one of the disadvantages of complement fixation test (CFT) and indirect immunofluorescent antibody tests (IFAT) (Khalil, 2012). Conversely, the cross-reactivity with Babesia caballi is the disadvantage of the enzyme-linked immunosorbent assay (ELISA) (Mahmoud et al., 2015). Recently, polymerase chain reaction (PCR) was able to detect the level of parasitemia at $0.0083 \%$ (Ibrahim et al., 2011). A review of the literature revealed a scarcity of publication regarding diagnosis and occurrence of equine theileriosis in Iraq. Therefore, this study intended to establish the occurrence of equine theileriosis in Al-Najaf province using molecular tools.

\section{Materials and Methods}

\section{Samples collections}

This study was carried out in 8 districts of Al-Najaf province during tick activity season. Blood samples were collected from 110 horses with more than two signs (mostly fever and jaundice) of piroplasmosis. Collected blood was immediately placed in tubes with anticoagulant, then submitted to the laboratory and stored in $-20^{\circ} \mathrm{C}$ until extraction of DNA.

\section{Genomic DNA extraction}

The DNA was extracted from stored blood Mini Kit (Geneaid Biotech Ltd., Taiwan). The process was carried out according to the instructions of company by using protocol of frozen blood extraction with the Proteinase K. The extracted gDNA product was then checked by Nanodrop spectrophotometer and stored at $-20 \mathrm{C}^{\circ}$ at refrigerator until amplification.

\section{Polymerase Chain Reaction (PCR)}

PCR assay was conducted by a specific primer, designed by Alhassan et al. (2005), to amplify a 392bp portion of highly conserved regions of $18 \mathrm{~S}$ ribosomal RNA in Theileria equi 18SrRNA. The forward primer (TCGAAGACGATCAGATACCGTCG), and reverse primer (TGCCTTAAACTTCCTTGCGAT) 18SrRNA were provided by Bioneer Corporation (Republic of Korea). The PCR master mix is prepared by AccuPower PCR PreMix kit manufactured by Bioneer. The tubes of PCR premix comprise pellets of freeze-dried Taq DNA polymerase $1 \mathrm{U}$, Tris- $\mathrm{HCl}$ (pH 9.0) 10mM, dNTPs $250 \mu \mathrm{M}, \mathrm{MgCl} 21.5 \mathrm{mM}, \mathrm{KCl} 30 \mathrm{mM}$, stabilizer, and tracking dye. The PCR reaction of master mix is prepared in total volume of $20 \mu \mathrm{l}$ by added purified genomic DNA $(5 \mu \mathrm{l})$, forward primer $(1 \mu \mathrm{l}$ of $10 \mathrm{pmole})$ and reverse primer ( $1 \mu \mathrm{l}$ of $10 \mathrm{pmole})$. The PCR premix tube was completed with $20 \mu$ deionizer PCR water, then briefly mixed by vortex centrifuge (Bioneer). The thermocycler $\left(\mathrm{T} 100^{\text {tw }}\right.$ Thermal Cycler, Bio-Rad, Hercules, CA USA) was set as; temperature of initial denaturation at $95^{\circ} \mathrm{C}$ for $5 \mathrm{~min}$; followed by denaturation 30 cycles at $95^{\circ} \mathrm{C}$ for $30 \mathrm{sec}$, annealing $60^{\circ} \mathrm{C}$ for $30 \mathrm{sec}$, and extension $72{ }^{\circ} \mathrm{C}$ for $30 \mathrm{sec}$ and, finally, extension at $72{ }^{\circ} \mathrm{C}$ for $7 \mathrm{~min}$. The products of PCR were inspected by $1 \%$ agarose gel electrophoresis, stained with ethidium bromide, and examined under UV illumination.

\section{Results}

Out of 110 samples, 42 showed a band of approximately $392 \mathrm{pb}$, which were considered positive to T. equi $18 \mathrm{~S}$ rRNA gene in a percentage of $38.18 \%$ (Figure 1 ). According to gender, the percentages of infection were $43.48 \%$ and $29.27 \%$ in females and males, respectively. The percentages of infection according to the age of horses were $50 \%$ and $35.22 \%$ in less than 2 years and above 2 years, respectively. The percentages of infection in the horses according to tick infestation 


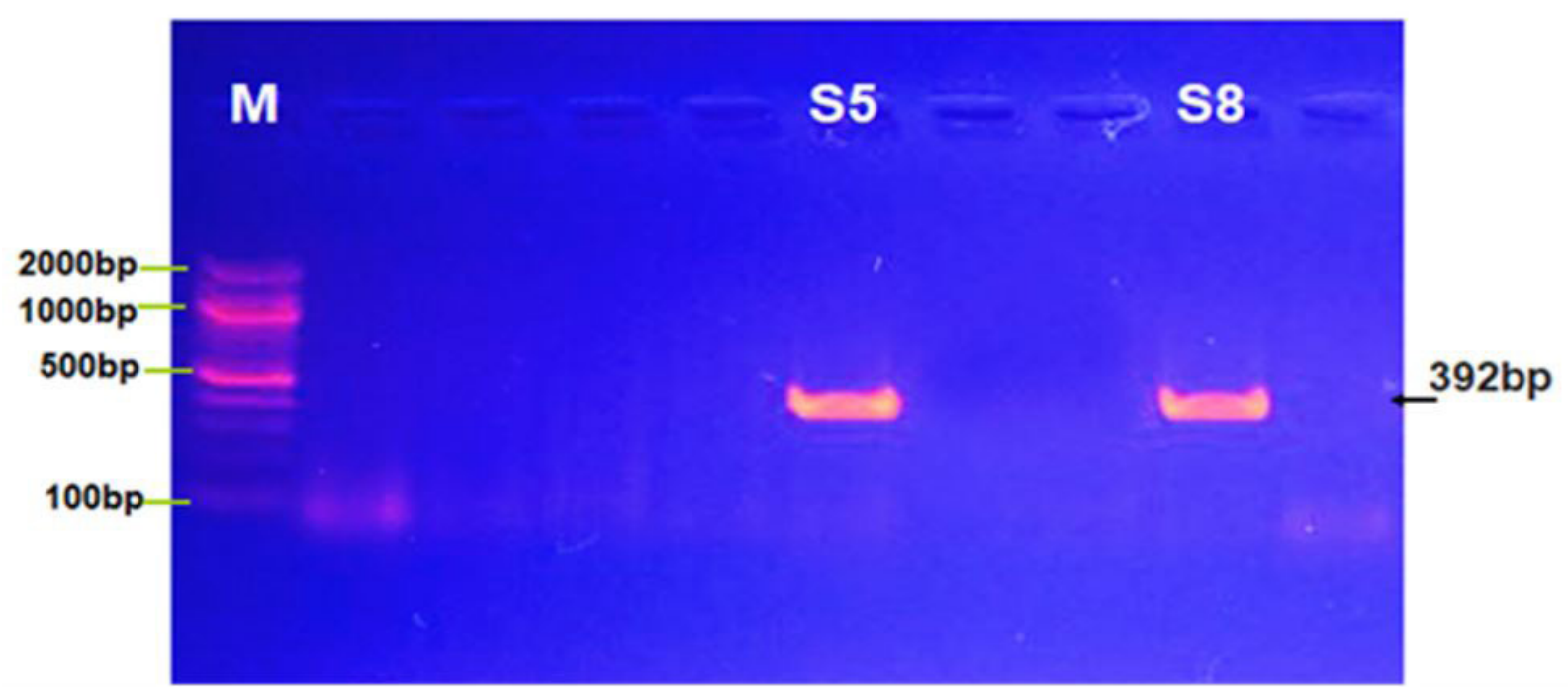

Figure 1 - Image agarose gel electrophoresis reveals the PCR marks for 18S rRNA gene in positive Theileria equi. Where M: Marker (2000-100bp), Lane (S5and S8) are positive samples at 392bp PCR product size.

Table 1 - The prevalence of equine theileriosis and associated factors in Al-Najaf/Iraq, 2013

\begin{tabular}{lccc}
\hline \multicolumn{1}{c}{ Factor } & No. examined & No.Positive & $\%$ \\
\hline Prevalence & 110 & 42 & 38.18 \\
Sex & & & \\
Male & 41 & 12 & 29.27 \\
Female & 69 & 30 & 43.48 \\
Age & & & \\
Immature(<2years) & 22 & 11 & 50 \\
Mature (>2 years) & 88 & 31 & 35.22 \\
Tick infestation & & & \\
Yes & 48 & 30 & 62.50 \\
No & 62 & 12 & 19.35 \\
Districts & & & \\
Abo-sker & 12 & 3 & 25 \\
Qadisiyia & 16 & 6 & 37.50 \\
Najaf center & 14 & 3 & 21.43 \\
Kufa & 14 & 4 & 28.57 \\
Hera & 23 & 14 & 60.87 \\
Hayderia & 8 & 3 & 37.50 \\
Baher Al-najaf & 13 & 5 & 38.46 \\
Abbasyia & 10 & 4 & 40 \\
\hline
\end{tabular}

were $62.5 \%$ and $19.35 \%$ in horses with acariasis and without acariasis, respectively. There was significant geographical variation in equine theileriosis, with the highest occurrence in Hera district (60.87\%), while the lowest was in the center of Al-Najaf (21.43\%), as presented in Table 1.

\section{Discussion}

Equine piroplasmosis has economic importance in the equestrian industry due to low performance in work and sports activities, restriction of transboundary movement, cost of hospitalization and high mortality rate of infected animals (Bahrami et al., 2014; Friedhoff et al., 1990; Malekifard et al., 2014). The current study proved the detection of Theileria equi of the 18S rRNA gene by PCR in 42 out of 110 samples, with percentages reaching $38.18 \%$ in horses suffering from main disease signs (pyrexia and icterus). This is close to the results of Aziz et al. (2019), who recorded the rate of occurrence of equine theileriosis diagnosed by PCR (41.91\%) in Erbil, Iraq, as well as the results being somewhat consistent with those of Saleem \& Al-Samarai (2018), who recorded 32\% in central Iraq. In the neighboring countries of Iraq Saudi Arabia (Alanazi et al., 2012), Jordan (Abutarbush et al., 2012), Iran (Abedi et al., 2014) and Turkey (Guven et al., 2017), the percentages were $10.14 \%, 14.6 \%, 48 \%$, and $8.8 \%$, respectively.

The diagnosis of equine theileriosis was a challenge for veterinary field practice as a microscopic examination of the suspected blood smear is unreliable, particularly in the low parasitic stage. Many serological tests have been used for the diagnosis of equine theileriosis, including ELISA, IFAT, and CFT. However, these techniques have low sensitivity and cross-reactivity with other blood protozoa (Abedi et al., 2014). Rampersad et al. (2003) found high accuracy of the molecular identification of T. equi, as the parasite can be diagnosed by PCR (18S ribosomal RNA genes) in $25 \mu \mathrm{l}$ blood with the parasitemia percentage of $0.00008 \%$.

The result of the current study showed gender variation in the occurrence of equine theileriosis. The female's percentage was $43.48 \%$, which was higher than the male's percentage of $29.27 \%$. These findings were similar to that concluded by Sray et al. (2019) and might be explained by the high exposure of mares to stress than males due to pregnancy or racing, whereas most local racing and religious rituals depend on mares. Many authors suggested that horses' hard exercise may compromise their immunity, resulting in the 
development of acute theileriosis in animals with carrier state (Hodgson, 2002).

The results of the present study demonstrated that the diseases were $50 \%$ more prevalent in immature horses. This finding may be due to placental transportation or bad management regime, whereas the foals aged less than 2 years were highly infested with ticks due to tick control neglect. This result agrees with many previous recorded studies that showed the occurrence of equine theileriosis in foals more than adult horses due to the exposure of foals to stress, which may lead to reduced immunity (Hodgson, 2002; Sevinc et al., 2008). This study showed variation in the percentage of equine theileriosis infection due to acariasis infestation. The high occurrence of disease (62.5\%) occurred in animals with tick infestation in comparison to tick-free animals. This result is compatible with previous studies that also documented many species of ticks as the biological vectors to equine theileriosis (Alanazi et al., 2012; Nava et al., 2009).

The result of this study also revealed variations in the occurrence of the disease according to a geographical area. The highest occurrence was recorded in rural district of Hera (21.43\%), while the lowest was in center of Al-Najaf (urban district). This difference may be due to different distribution

\section{References}

Abedi V, Razmi G, Seifi H, Naghibi A. Molecular and serological detection of Theileria equi and Babesia caballi infection in horses and ixodid ticks in Iran. Ticks Tick Borne Dis. 2014;5(3):239-44. http://dx.doi.org/10.1016/j. ttbdis.2013.11.008. PMid:24556274.

Abutarbush SM, Alqawasmeh DM, Mukbel RM, Al - Majali AM. Equine babesiosis: seroprevalence, risk factors and comparison of different diagnostic methods in Jordan. Transbound Emerg Dis. 2012;59(1):72-8. http://dx.doi. org/10.1111/j.1865-1682.2011.01244.x. PMid:21771287.

Alanazi AD, Alyousif MS, Hassieb MM. Seroprevalence study on Theileria equi and Babesia caballi antibodies in horses from central province of Saudi Arabia. J Parasitol. 2012;98(5):1015-7. http://dx.doi.org/10.1645/GE-2997.1. PMid:22489955.

Alhassan A, Pumidonming W, Okamura M, Hirata H, Battsetseg B, Fujisaki K, Yokoyama N, Igarashi I. Development of a single-round and multiplex PCR method for the simultaneous detection of Babesia caballi and Babesia equi in horse blood. Vet Parasitol. 2005;129(1-2):43-9. http:// dx.doi.org/10.1016/j.vetpar.2004.12.018. PMid:15817201. of vector of disease (tick), which may be the availability of the suitable weather that helped in the multiplication of the intermediate vectors (Javed et al., 2014).

\section{Conclusion}

This study proved the detection of Theileria equi of the $18 \mathrm{~S}$ rRNA gene by PCR in Arabian horses in Al-Najaf province/Iraq. Moreover, the variations in the occurrences of equine piroplasmosis according to gender, age, and geographical areas were also reported.

\section{Conflict of Interest}

The authors declare that there is no conflict of interest.

\section{Ethics Statement}

Ethics approval was approved by Faculty of Veterinary Medicine/ University of Kufa.

\section{Acknowledgements}

The authors extend their thanks and gratitude to everyone who helped in carrying out this research, especially the Arabian horse breeder in the city of Najaf and the molecular analysis laboratory in the city of Qadisiyah.

Aziz KJ, AL-Barwary LTO, Mohammed ZA, Naqid IA. AL-Barwary, LTO, Mohammed ZA, Naqid IA. Molecular identification and phylogenetic analysis of Theileria equi and Babesia caballi infections in equids from Erbil Province, North of Iraq. Adv. Anim. Vet. Sci. 2019;7(12):1060-6. http:// dx.doi.org/10.17582/journal.aavs/2019/7.12.1060.1066.

Bahrami S, Ghadrdan AR, Pourmahdi Borujeni M, Vafayi Salarpur M. Epidemiology of Theileria equi in Persian Arab horses from Iran. Vet Med. 2014;59(9):409-14. http://dx.doi. org/10.17221/7680-VETMED.

Butler CM, Van Oldruitenborgh-Oosterbaan MMS, Stout TAE, Van der Kolk JH, Wollenberg L, Nielen M, Jongejan F, Werners AH, Houwers DJ. Occurrence of causative agent of equine piroplasmosis in South West of the Netherland and identification of two autochthonous clinical Theileria equi infection. Vet J. 2012;193(2):381-5. http://dx.doi. org/10.1016/j.tvjl.2011.12.014. PMid:22266019.

Friedhoff KT, Tenter AM, Muller I. Hemoparasites of equines: impact on international trade of horses. Rev Sci Tech. 1990;9(4):1187-94. http://dx.doi.org/10.20506/ rst.9.4.535. PMid:2132711. 
Guven E, Avcioglu H, Deniz A, Balkaya İ, Abay U, Yavuz S, Akyüz M. Prevalence and molecular characterization of Theileria equi and Babesia caballi in jereed horses in Erzurum, Turkey. Acta Parasitol. 2017;62(1):207-13. http:// dx.doi.org/10.1515/ap-2017-0025. PMid:28030350.

Hodgson J. Equine exotic diseases, a manual for horse owners. Canberra: Union Offset; 2002; p. 47-49. (RIRDC Publication; 02/054).

Ibrahim AK, Gamil IS, Abd-El Baky AA, Hussein MM, Tohamy AA. Comparative molecular and conventional detection methods of Babesia equi in Egyptian equine. Glob Vet. 2011;7(2):201-10.

Javed K, Ijaz M, Ali MM, Khan I, Mehmood K, Ali S. Prevalence and hematology of tick borne hemoparasitic diseases in equines in and around Lahore Pakistan. J Zool. 2014;46(2):401-8.

Khalil SS. Epidemiology, diagnosis and therapy of Theileria equi infection in Giza, Egypt [thesis]. Cairo: Faculty of Veterinary Medicine, University of Cairo; 2012.

Kumar S, Malhotra DV, Sangwan AK, Goel P, Kumar A, Kumar S. Infectivity rate and transmission potential of Hyalomma anatolicum anatolicum ticks for Babesia equi infection. Vet Parasitol. 2007;144(3-4):338-43. http://dx.doi. org/10.1016/j.vetpar.2006.10.009. PMid:17112671.

Mahdy OA, Nassar AM, Mohamed BS, Mahmoud MS. Comparative diagnosis utilizing molecular and serological techniques of Theileria equi infection in distinct equine populations in Egypt. Int J Chemtech Res. 2016;9(6):185-97.

Mahmoud MS, El-Hakim AE, Hendawy SHM, Shalaby HA, Kandil OM, Abu El-Ez NT. Diagnosis of Theilria equi infections in equines using immunoaffinity purified antigen. Glob Vet. 2015;15(2):192-201.

Malekifard F, Tavassoli M, Yakhchali M, Darvishzadeh R. Detection of Theileria equi and Babesia caballi using microscopic and molecular methods in horses in suburb of Urmia, Iran. Vet Res Forum. 2014;5(2):129-33. PMid:25568706.
Nava S, Mangold AJ, Mastropaolo M, Venzal JM, Oscherov EB, Guglielmone AA. Amblyomma boeroin sp. (Acari: Ixodidae), a parasite of the Chacoan peccary Catagonus wagneri (Rusconi) (Artiodactyla:Tayassuidae) in Argentina. Syst Parasitol. 2009;73(3):161-74. http://dx.doi.org/10.1007/ s11230-009-9191-9. PMid:19472076.

Rampersad J, Cesar E, Campbell MD, Samlal M, Ammons D. A field PCR for the routine detection of Babesia equi in horses. Vet Parasitol. 2003;114(2):81-7. http://dx.doi. org/10.1016/S0304-4017(03)00129-8. PMid:12781470.

Saleem HD, Al-Samarai FR. Prevalence of Theileria equi in horses in central Iraq determined by microscopy and PCR. Online J Vet Res. 2018;22(4):273-80.

Schein E. Equine babesiosis. In: Ristic M, editor. Babesiosis of domestic animals and man. Boca Raton: CRC Press; 1988. p. 197-208.

Sevinc F, Maden M, Kumas C, Sevinc M, Ekici OD. A comparative study on the prevalence of Theileria equi and Babesia caballi infections in horse subpopulations in Turkey. Vet Parasitol. 2008;156(3-4):173-7. http://dx.doi. org/10.1016/j.vetpar.2008.06.006. PMid:18672330.

Sray HK, Al-Shabani HA, Ghabran AJ. Serological and molecular estimation of Theileria equi Infections in horses of Baghdad, Al-Qadisiyah, and Wasit Provinces/Iraq. J Res Lepid. 2019;50(4):391-404. http://dx.doi.org/10.36872/ LEPI/V50I4/201103.

Waal DT. Equine piroplasmosis: a review. Br Vet J. 1992;148(1):614. http://dx.doi.org/10.1016/0007-1935(92)90061-5. PMid:1551016.

Wise LN, Kappmeyer LS, Mealey RH, Knowles DP. Review of equine piroplasmosis. J Vet Intern Med. 2013;27(6):133446. http://dx.doi.org/10.1111/jvim.12168. PMid:24033559.

Zobba R, Ardu M, Niccolini S, Chessa B, Manna L, Cocco R, Pinna Parpaglia ML. Clinical and laboratory findings in equine piroplasmosis. J Equine Vet Sci. 2008;28(5):301-8. http://dx.doi.org/10.1016/j.jevs.2008.03.005. 